\title{
FACEBOOK A POLITYKA. WYKORZYSTANIE SERWISÓW SPOŁECZNOŚCIOWYCH PRZEZ POLSKIE PARTIE POLITYCZNE
}

\author{
Leszek Porębski*, Kinga Karasek-Kędzior** \\ FACEBOOK AND POLITICS. THE USE OF SOCIAL NETWORKS BY \\ POLISH POLITICAL PARTIES
}

\begin{abstract}
- ABSTRACT
The paper presents results of the research project that explored the mode in which Polish political parties use their Facebook profiles. The findings of the analysis prove that interactive and multimedia aspect of social networking is employed only in a limited degree. Party profiles are not used as a platform of the information on party activity distribution. Even basic contact data is not available on each of analyzed profiles. Moreover, as was expected, there is no clear association between the technical sophistication of the specific party profile and the position of the party on political market. Parties which are leaders of the ICT (Information and Communication Technologies) use are not dominating in terms of both possessed resources and the role played in parliamentary politics.
\end{abstract}

KEYWORDS —

political parties, social networks, political communication

* AGH w Krakowie, Katedra Politologii i Historii Najnowszej.

** AGH w Krakowie, Katedra Politologii i Historii Najnowszej. 


\section{WPROWADZENIE}

Pytanie o relacje pomiędzy polityką a rozwojem technologicznym towarzyszy badaczom co najmniej od momentu, gdy w starożytnym Rzymie zaczęto wykorzystywać gliniane tablice do sporządzania reklam o charakterze politycznym. Współcześnie, wraz z gwałtownym rozwojem technologii informacyjnych i komunikacyjnych (Information and Communication Technologies - ICT), zwanym zazwyczaj z rewolucją informacyjną, problem wpływu technologii na kształt życia politycznego ponownie nabrał wyjątkowej aktualności. W tym kontekście już na początku ostatniej dekady ubiegłego wieku pojawiły się rozważania na temat elektronicznej demokracji - modelu politycznego, w którym ICT zmieniają nie tylko formę, ale i samą treść procesów i procedur politycznych. Abstrahując w tym miejscu od szczegółów debaty wokół statusu i realnego znaczenia elektronicznej demokracji, trzeba jednak uznać, że analiza obecności nowych technologii w różnych aspektach życia politycznego stała się trwałym elementem nauki o polityce.

Dyskusja na temat, w jaki sposób Internet i inne ICT wpływają na kształt współczesnej demokracji, jest zresztą tylko „fragmentem większej całości”. Jeżeli co trzeci mieszkaniec globu jest obecnie użytkownikiem siecii , to poziom zdeterminowania życia codziennego przez ICT - zwłaszcza w krajach najbardziej rozwiniętych - czyni z nowych technologii jeden z najgorętszych tematów dla wszystkich badaczy życia społecznego. Nowe typy więzi społecznych, zachowania konsumenckie w elektronicznym handlu czy globalny przekaz kulturowy realizowany dzięki i poprzez ICT to tylko kilka spośród wielu wątków poddawanych analizie z socjologicznego, antropologicznego czy psychologicznego punktu widzenia. Rozważania nad powodowanymi przez rewolucję informacyjną przemianami życia politycznego uzupełniają tylko refleksję nad współczesnością o kolejny, istotny element. Paradoksalnie więc to rozwój technologii stał się czynnikiem przyspieszającym realizację postulatu interdyscyplinarności - od wielu dekad stawianego jako wyzwanie stojące przed naukami społecznymi. W dniu dzisiejszym konieczność integracji badań, choćby dla pełniejszego zrozumienia wpływu ICT na współczesnego człowieka, wydaje się znacznie bardziej oczywista niż jeszcze kilka dekad wstecz.

${ }^{1}$ Według danych na 30 czerwca 2012 roku światowa populacja internautów liczyła ponad 2,4 mld osób, co stanowiło ok. 34\% mieszkańców Ziemi. Zob. http://www.internetworldstats.com/stats.html, odczyt z dn. 10.05.2013. 


\section{NOWE TECHNOLOGIE INFORMACYJNE I KOMUNIKACYJNE JAKO PRZEDMIOT ZAINTERESOWANIA BADAŃ NAD KOMUNIKOWANIEM POLITYCZNYM}

Empiryczne badania nad nowymi technologiami rozumianymi jako czynnik zmieniający obraz współczesnej polityki nie mają charakteru jednorodnego i obejmują co najmniej kilka istotnych kwestii. Wśród najistotniejszych warto wymienić analizę wykorzystania ICT w działalności instytucji publicznych², problem elektronicznego aktywizmu politycznego czy wreszcie refleksję nad różnymi aspektami elektronicznego głosowania. Oczywiście jednym z kluczowych zagadnień, które są intensywnie eksplorowane w kontekście roli odgrywanej przez nowe technologie, jest także szeroko rozumiany problem politycznej komunikacji. Kwestia ta budzi zainteresowanie zarówno ze strony politologów, analizujących wpływ różnych form komunikowania na funkcjonowanie systemu demokratycznego, jak i badaczy, dla których sieciowe komunikowanie polityczne to tylko jeden $\mathrm{z}$ aspektów analizy przemian w procesie komunikacji wywoływanych przez ICT.

Niezależnie od podejścia badawczego zdecydowanie najwięcej analiz poświęconych jest dwóm typom narzędzi internetowej komunikacji. Są nimi blogi oraz witryny sieciowe. Nie jest to niczym zaskakującym, bo strony internetowe to chronologicznie pierwsza i do dzisiaj powszechnie wykorzystywana forma obecności w sieci. Witryny w sposób wyjątkowo efektywny wykorzystują wszystkie podstawowe atrybuty Internetu - multimedialność, interaktywność i hipertekstualność - co sprawiło, że wielu użytkowników, korzystając z sieci, ciągle jeszcze ogranicza się do przeglądania stron WWW.

Z kolei blogi są najbardziej dostępnym i w związku z tym najpopularniejszym narzędziem komunikacji sieciowej, pozostającym do dyspozycji tych spośród indywidualnych użytkowników, którzy chcą dotrzeć do większej liczby odbiorców. Jest to więc ulubiona forma aktywności ludzi o niezrealizowanych ambicjach

2 Problem ten jest zazwyczaj określany terminem elektroniczna administracja (e-government), a różne jego aspekty mają w zasadzie status odrębnej subdyscypliny badawczej i doczekały się obszernej literatury. Zob. np. E-government Diffusion, Policy and Impact: Advanced Issues and Practices, red. M. Khosrow-Pour, Hershey 2009; Politics, Democracy and E-government, red. H. Reddick, Hershey 2010; L. Porębski, Polish E-Government at Local Level: Heavy Road to Citizens' Empowerment, [w:] ICDS 2012, The Sixth International Conference on Digital Society, red. J.L. Mauri, G. Martinez, L. Berntzen, A. Smedberg, Valencia 2012, s. 1-6, http://www.thinkmind.org/index.php?view=article\&articleid=icds_2012_1_10_10023, odczyt z dn. 10.05.2013. 
literackich, hobbistów czy szukających bratniej duszy nastolatków. Ze względu na logikę procesów demokratycznych aktorzy polityczni stanowią oczywiście jedną z grup najbardziej zainteresowanych utrzymywaniem tego typu kontaktów $\mathrm{z}$ internautami. Ci ostatni są $\mathrm{w}$ tym kontekście postrzegani jako członkowie wspólnoty politycznej - obywatele, a często po prostu jako potencjalni wyborcy.

Wśród studiów poświęconych wykorzystaniu stron internetowych znaleźć można przede wszystkim analizy witryn polityków - głównie parlamentarzystów w konkretnych krajach, ale także badania o charakterze porównawczym ${ }^{3}$. Nie brakuje jednak także opisów sposobu korzystania $\mathrm{z}$ witryn przez konkretne partie polityczne oraz ruchy społeczne zaangażowane w życie publiczne, od ekologii przez działalność w obronie praw człowieka aż po aktywność na rzecz mniejszości seksualnych ${ }^{4}$.W spomniane analizy podejmują szereg szczegółowych problemów badawczych. Najbardziej ogólny z nich to próba wskazania podstawowych funkcji pełnionych przez witryny - zarówno w przypadku stron indywidualnych polityków, jak i tych tworzonych przez organizacje polityczne. Badana bywa jednak również intensywność korzystania z witryny przez użytkowników, a także zależność pomiędzy społeczną i demograficzną charakterystyką polityka a jego skłonnością do wykorzystywania ICT ${ }^{5}$.

W przypadku blogów politycznych - które prowadzone są zarówno przez polityków, jak i publicystów, komentatorów czy przeciętnych konsumentów polityki - mamy do czynienia ze znacznie szerszym spektrum analizowanych zagadnień. Przede wszystkim jest to sam, charakterystyczny dla narzędzi sieciowych, model komunikacji. W równym stopniu przedmiotem badań jest jednak także wpływ treści publikowanych na blogach na kształt - i jakość - debaty

3 Zob. np. S. Ward, W. Lusoli, From 'Weird' to 'Wired': MPs, the Internet and Representative Politics in the UK, „The Journal of Legislative Studies” 2005, vol. 11, nr 1, s. 57-81; M. Lindh, L. Miles, Becoming Electronic Parliamentarians? ICT Usage in the Swedish Riksdag, ,The Journal of Legislative Studies" 2007, vol. 13, nr 3, s. 422-440; J. Stanyer, Elected Representatives, Online Self-Presentation and Personal Vote: Party, Personality and Webstyles in the United States and United Kingdom, „Information, Communication \& Society" 2008, vol. 11, issue 3, s. 414-432.

${ }^{4}$ R. Gibson, S. Ward, Virtual Campaigning: Australian Parties and the Impact of the Internet, "Australian Journal of Political Science” 2002, vol. 37, nr 1, s. 99-129; L. March, Russian Parties and the Political Internet, „Europe-Asia Studies” 2004, vol. 56, nr 3, s. 369-400; L. Stein, Social Movement Web Use in Theory and Practice: A Content Analysis of US Movement Websites, „New Media \& Society” 2009, vol. 11, nr 5, s. 749-771.

${ }^{5}$ Analiza witryn brytyjskich parlamentarzystów dowiodła, że najważniejsze czynniki determinujące gotowość do korzystania z ICT to wiek deputowanych i długość stażu parlamentarnego. Politycy najstarsi i najdłużej obecni w parlamencie zdecydowanie rzadziej mieli własne witryny. Zob. S. Ward, W. Lusoli, op.cit., s. 68 . 
publicznej czy skuteczność blogów w mobilizowaniu zwolenników wokół konkretnych postulatów politycznych ${ }^{6}$.

Warto jednocześnie zauważyć, że rozwój ICT ma charakter ciągły, stąd konieczność objęcia analizą narzędzi, które jeszcze kilka lat temu nie istniały, a obecnie odgrywają coraz istotniejszą rolę wśród użytkowników sieci. Najbardziej spektakularnym przykładem tego typu jest Twitter, serwis pozwalający na wysyłanie krótkich wiadomości (maksymalnie 140 znaków) - forma pośrednia pomiędzy mikroblogiem a serwisem społecznościowym. Usługa ta została udostępniona jesienią 2006 roku, a pod koniec roku 2012 w ciągu każdego miesiąca korzystało z niej aktywnie około 200 milionów osób, wysyłających prawie 500 milionów wiadomości w ciągu każdego dnia7. Ma to swoje konsekwencje także w sferze komunikowania politycznego. Politycy coraz intensywniej wykorzystują Twittera, co zaowocowało pierwszymi próbami opisu tego typu komunikacji i roli odgrywanej przez nią w różnych - głównie wyborczych aspektach polityki ${ }^{8}$. Niewątpliwie kolejne lata przyniosą znacznie więcej opracowań tego typu, a tempo przemian ICT sprawia, że dzisiaj trudno przewidzieć, które narzędzia sieciowej komunikacji politycznej będą głównym przedmiotem analiz w najbliższej przyszłości.

\section{CEL, ZAKRES I METODA BADAŃ}

Zaprezentowany powyżej skrótowo stan badań nad wykorzystaniem ICT w komunikowaniu politycznym wymaga uzupełnienia o co najmniej dwie istotne uwagi. Po pierwsze, nie tylko Twitter jest ciągle jeszcze bardzo rzadko przedmiotem analizy. Analogiczna sytuacja dotyczy także sposobu korzystania przez aktorów politycznych z serwisów społecznościowych. Mimo iż stworzyły one w ostatnich latach zupełnie nowe możliwości sieciowej aktywności i są

${ }^{6}$ Zob. np. S. Coleman, Blogs and the New Politics of Listening, „Political Quarterly” 2005, vol. 76, issue 2, s. 272-280; G. Lawson-Borders, R. Kirk, Blogs in Campaign Communication, „American Behavioral Scientist" 2005, vol. 49, nr 4, s. 548-559; K. Grabianowska, Odzwierciedlenie rzeczywistych poglądów czy czysta propaganda - blogi polityków, [w:] Media w Polsce: Pierwsza władza IV RP?, red. M. Sokołowski, Warszawa 2007.

7 G. Beato, Twitter: Free Speech in 140 Characters, „Reason” 2013, vol. 44, nr 10, s. 28-34.

${ }^{8}$ J. Golbeck, J. Grimes, A. Rogers, Twitter Use by the US Congress, „Journal of the American Society for Information Science and Technology" 2010, vol. 61, issue 8, s. 1612-1621; A. Larsson, H. Moe, Studying Political Microblogging: Twitter Users in the 2010 Swedish election Campaign, „New Media \& Society" 2012, vol. 14, issue 5, s. 729-747. 
obecnie używane przez setki milionów osób ${ }^{9}$, politolodzy znacznie chętniej badają bardziej tradycyjne narzędzia dostępne w sieci ${ }^{10}$. Po drugie, zdecydowana większość wspomnianych studiów dotyczy kampanii wyborczych i związanej z nimi specyficznej aktywności aktorów politycznych. Analizowana jest więc przede wszystkim intensywność wykorzystywania serwisów społecznościowych w okresie wyborczym, różne modele mobilizacji wyborców czy poziom interaktywności w kampanijnej komunikacji.

Wszystkie sformułowane dotychczas uwagi dotyczą także analiz polskiej sceny politycznej prowadzonych przez polskich badaczy. Przedmiotem zainteresowania był do tej pory przede wszystkim okres kampanii wyborczej, a główny akcent padał na strony internetowe partii politycznych czy konkretnych kandydatów ${ }^{11}$. W tym kontekście badany był poziom multimedialności i interaktywności witryn, częstotliwość umieszczania nowych materiałów czy treść tekstów umieszczanych w sieci.

Opisany stan badań stał się punktem wyjścia do realizacji projektu, którego wyniki zostaną zaprezentowane w dalszej części tego tekstu. Za przedmiot analizy została wybrana aktywność polskich partii politycznych realizowana przy pomocy Facebooka, najpopularniejszego obecnie serwisu społecznościowego. Świadomie jednak głównym przedmiotem badań uczyniono okres, który nie miał charakteru wyborczego - marzec roku 2012. Był to moment, gdy minęło już pięć miesięcy od wyborów parlamentarnych (9 października

9 W grudniu 2012 roku każdego dnia średnio korzystało z Facebooka 618 milionów osób. Zob. D. Tam, Facebook by the Numbers: 1,06 Bilion Monthly Active Users, CNet, 30 January 2013, http:// news.cnet.com/ 8301-1023_3-57566550-93/facebook-by-the-numbers-1.06-billion-monthlyactive-users/, odczyt z dn. 14.06.2013.

10 Do nielicznych opracowań poświęconych roli odgrywanej przez serwisy społecznościowe w aktywności politycznej można zaliczyć np.: G. Baxter, R. Marcella, Does Scotland 'like' This? Social Media Use by Political Parties and Candidates in Scotland during the 2010 UK General Election Campaign, „Libri” 2012, vol. 62, s. 109-124; N. Gustafsson, The Subtle Nature of Facebook Politics. Swedish Social Network Side Users and Political Participation, „New Media \& Society” 2012, vol. 14, nr 7, s. 1111-1127; Ch. Williams, G. Gulati, Social Networks in Political Campaigns: Facebook and the Congressional Elections of 2006 and 2008, „New Media \& Society” 2013, vol. 15, nr 1, s. 52-71.

11 Zob. np. J. Żurawski, Internet jako współczesny środek elektronicznej komunikacji wyborczej, Kraków 2010; B. Dobek-Ostrowska, P. Baranowski, Witryny internetowe partii politycznych jako narzędzie komunikowania wyborczego w kampanii parlamentarnej w 2011 roku, ,Studia Politologiczne" 2012, vol. 24, s. 104-131. Analizą wykorzystania serwisów społecznościowych, ale także w kontekście wyborczym zajmowała się Ilona Grzywińska. Zob. I. Grzywińska, Analiza komunikacja politycznej w serwisach społecznościowych (NK.pl i Facebook.com) podczas prezydenckiej kampanii wyborczej 2010 roku, „Studia Politologiczne” 2011, vol. 21, s. 131-164. 
2011), a najbliższa kampania wyborcza miała odbyć się dopiero za dwa lata. Poddanie analizie okresu pozbawionego bezpośrednich związków z wyborczą mobilizacją polityczną pozwoliło ocenić, na ile serwisy społecznościowe stały się elementem codziennego, rutynowego funkcjonowania polskich partii politycznych. Badania stanowiły próbę znalezienia odpowiedzi na kilka szczegółowych pytań: Jak intensywnie polskie partie polityczne korzystają z narzędzi typu Facebook w okresie niemającym charakteru wyborczego? W jakim stopniu wykorzystywane są multimedialne i interaktywne możliwości stwarzane przez serwisy społecznościowe? Czy istnieją istotne różnice w sposobie korzystania z Facebooka pomiędzy partiami parlamentarnymi i tymi, które pozostają poza parlamentem?

Analizie poddano dostępne na Facebooku profile ośmiu partii politycznych. Sześć z nich ma swoich przedstawicieli w parlamencie. Są nimi: Platforma Obywatelska (PO), Prawo i Sprawiedliwość (PiS), Ruch Palikota (RP), Sojusz Lewicy Demokratycznej (SLD), Polskie Stronnictwo Ludowe (PSL) oraz Solidarna Polska (SP). Dwie pozostałe partie nie są reprezentowane w parlamencie. Są to: Kongres Nowej Prawicy (KNP) oraz Zieloni 2004.

W badaniach zastosowano metodę ilościowej i jakościowej analizy zawartości. Na podstawie wstępnej fazy pilotażowej dla przeprowadzenia właściwych badań stworzony został klucz kategoryzacyjny, za pomocą którego poddano analizie zawartość profilu partii od momentu jego uruchomienia do momentu zakończenia badań (31 marca 2012). Analiza obejmowała trzy podstawowe kategorie, którym przypisano 12 szczegółowych kryteriów. Wspomniane kategorie to: typ materiałów dostępnych na profilu (4 kryteria), statystyki dotyczące aktywności użytkowników profilu ${ }^{12}$ (3 kryteria) oraz typ danych kontaktowych dostępnych na profilu (5 kryteriów).

W toku wstępnej analizy zgromadzonych danych sformułowane zostały dwie hipotezy badawcze: (1) partie polityczne w niewielkim stopniu wykorzystują na swych profilach interaktywne i multimedialne możliwości stwarzane przez sieć oraz (2) znaczenie odgrywane przez partię polityczną na scenie publicznej nie ma wpływu na intensywność wykorzystywania przez tę partię serwisów społecznościowych oraz na aktywność użytkowników na partyjnych profilach.

12 Statystyki tego typu (np. liczba znaczników „lubię to”, najpopularniejsza grupa wiekowa wśród użytkowników itp.) dotyczące różnych profili generuje i udostępnia Facebook. 


\section{POLSKIE PARTIE POLITYCZNE NA FACEBOOKU. ANALIZA WYNIKÓW BADAŃ}

Facebook umożliwia użytkownikom publikację na swych profilach różnego rodzaju materiałów. Trzy podstawowe z nich to zdjęcia, filmy oraz „wydarzenia”. Ta ostatnia kategoria oznacza możliwość poinformowania o konkretnym przedsięwzięciu, które jest organizowane przez użytkownika lub w którym po prostu bierze on udział. W kontekście aktywności partii politycznych dotyczy to np. spotkań z wyborcami, debat czy manifestacji. Wyniki badań dotyczące typu materiałów dostępnych na profilach partii politycznych prezentuje tabela 1 .

Zaprezentowane dane dowodzą, że zdecydowanie najpopularniejszym sposobem prezentowania informacji o działalności partii politycznych jest publikacja zdjęć ( $w$ przeciwieństwie do filmów, których niewielką liczbę umieścił na swym profilu jedynie Ruch Palikota). Na analizowanych profilach znalazło się w sumie 5109 fotografii, co stanowi prawie 98\% wszystkich dostępnych materiałów. Warto zwrócić uwagę na istniejące różnice w liczbie fotografii umieszczanych na poszczególnych profilach. Liderująca w tym zakresie SP (1596 zdjęć) opublikowała ponad siedmiokrotnie więcej tego typu materiałów niż najbardziej „oszczędne” PSL (218 zdjęć). Należy jednocześnie pamiętać, że przytoczone dane dotyczą liczby materiałów umieszczonych od początku istnienia profilu danej partii. Ponieważ profile powstawały w różnym czasie $^{13}$, przeanalizowano także statystyczną liczbę zdjęć publikowaną na danym profilu w ciągu jednego dnia. Także w tym przypadku absolutnym liderem pozostaje SP, która umieszczała dziennie ponad 11 fotografii $(11,08)$, podczas gdy drugie w tej klasyfikacji PiS publikowało nieco ponad jedno zdjęcie dziennie $(1,37)^{14}$.

W przeciwieństwie do publikacji zdjęć partie polityczne w niewielkim stopniu wykorzystują do informowania o swej działalności udostępniony przez Facebooka serwis „Wydarzenia”. Na wszystkich analizowanych profilach kategoria „Wydarzenia” została wykorzystana zaledwie 76 razy, co stanowi tylko około 1,5\% wszystkich analizowanych materiałów. Trzy spośród ośmiu badanych partii (PO, RP i PSL) nie umieściły na swoich profilach żadnych wydarzeń. Z kolei zdecydowanie najintensywniej ten typ treści wykorzystywały partia Zieloni

13 Spośród analizowanych partii najwcześniej swój profil uruchomili Zieloni 2004 (31.01.2009), a najpóźniej Solidarna Polska (23.11.2011).

${ }^{14} \mathrm{~W}$ przypadku pozostałych partii odpowiednie wartości są następujące: SLD - 1,28; RP - 0,8; KNP - 0,8; PO - 0,52; Zieloni 2004-0,33; PSL - 0,23. 
Tabela 1. Typ materiałów dostępny na profilach partii politycznych

\begin{tabular}{|c|c|c|c|c|c|}
\hline Nazwa partii & Zdjęcia & Filmy & Wydarzenia & Inne & Razem \\
\hline PO & 499 & 0 & 0 & 5 & 504 \\
PiS & 1321 & 0 & 3 & 0 & 1324 \\
RP & 511 & 17 & 0 & 4 & 532 \\
PSL & 218 & 0 & 0 & 9 & 227 \\
SLD & 356 & 0 & 27 & 1 & 384 \\
SP & 1596 & 0 & 1 & 3 & 1600 \\
KNP & 309 & 0 & 12 & 0 & 321 \\
Zieloni 2004 & 299 & 0 & 33 & 0 & 332 \\
\hline Razem & 5109 & 17 & 76 & 22 & 5224 \\
\hline
\end{tabular}

Źródło: opracowanie własne.

2004 i SLD (odpowiednio: 33 i 27 wydarzeń). Co istotne i charakterystyczne, we wszystkich przypadkach opublikowane informacje dotyczyły wydarzeń, które już się odbyły. Innymi słowy, analizowany serwis jest traktowany jako kronika tego, co już się wydarzyło, a nie miejsce służące dystrybucji informacji o imprezach, które dopiero mają się odbyć ${ }^{15}$. Tematyka opisywanych na Facebooku wydarzeń była bardzo różnorodna. Najczęściej związane były one z ideową aktywnością poszczególnych partii (manifestacja przeciw GMO - Zieloni 2004; konferencja na temat równości płci - SLD), ale zdarzały się informacje o charakterze czysto kronikarskim. Jedynym wydarzeniem odnotowanym na profilu Solidarnej Polski była informacja o wizycie posłanki Beaty Kempy w Raciborzu.

Niespełna pół procenta $(0,4 \%)$ wszystkich umieszczanych na profilach materiałów stanowią treści, które nie mieszczą się w omawianych wcześniej kategoriach i zostały zaklasyfikowane jako „inne”. Są one przejawem inwencji osób odpowiadających za prezentację poszczególnych partii na Facebooku i pokazują zindywidualizowane podejście do możliwości stwarzanych przez serwisy społecznościowe. Najwięcej tego typu materiałów dostępnych jest na profilu PSL. Wśród nich znaleźć można zakładkę „Witamy!” (zawierającą logo partii, zdjęcie lidera oraz zaproszenie do przyłączenia się do stronnictwa), możliwość posłuchania partyjnej piosenki wyborczej, tekst programu wyborczego, a także odnośniki do innych serwisów partii dostępnych w Internecie (np. Blip,

15 Funkcję informacyjną pełnił w przypadku niektórych ugrupowań inny element profilu - „Tablica”, na której informacje o różnych imprezach umieszczały (niezbyt często) partie niewykorzystujące w ogóle kategorii „Wydarzenia”. Tak było np. w przypadku PO, RP czy PSL. 
Nasza Klasa, Twitter, YouTube). Wśród innych, wychodzących poza podstawowy standard, serwisów dostępnych na profilach partii na Facebooku warto zwrócić uwagę na zakładkę „Znajdź swojego parlamentarzystę” - udostępnioną przez PO, a także aplikację umożliwiającą wstąpienie w szeregi partii, dostępną na profilu Solidarnej Polski. Ta ostatnia „usługa” jest najlepszym - choć w polskiej polityce ciągle odosobnionym - przykładem wykorzystywania serwisów społecznościowych do budowania więzi z otoczeniem i organizacyjnego wzmacniania struktur.

Druga analizowana kategoria to udostępniane przez Facebooka statystyki dotyczące aktywności użytkowników konkretnego profilu (zob. tabela 2). O ile prezentowane powyżej dane na temat typu materiałów dostępnych na profilach pozwalały ocenić aktywność poszczególnych partii w kreowaniu i kształtowaniu oferty dla odbiorców serwisów społecznościowych, o tyle statystyki aktywności użytkowników obrazują realny "popyt” na opisaną ofertę.

Z tego punktu widzenia warto zwrócić uwagę na kilka istotnych kwestii.

Po pierwsze, poziom zainteresowania polskich użytkowników serwisów społecznościowych profilami partii politycznych jest niewielki. Biorąc pod uwagę, że już na koniec roku 2011 liczba użytkowników Facebooka w Polsce wynosiła około 7,5 miliona ${ }^{16}$, to sumaryczna liczba „polubień" profili partii politycznych, wynosząca w marcu 2012 roku nieco ponad 165 tysięcy nie może imponować. Oznacza to, że zaledwie nieco ponad 2\% użytkowników Facebooka polubiło którykolwiek spośród badanych profili partii politycznych. Można oczywiście przyjąć, że osoby korzystające z Facebooka wyjątkowo oszczędnie szafują kategorią „Lubię to!” w odniesieniu do wszystkich odwiedzanych przez siebie stron i profili. Teza ta jest jednak trudna do obrony w kontekście danych wskazujących, że w samym roku 2012 liczba „polubień” dokonanych wyłącznie na profilach firm komercyjnych wyniosła ponad 117 milionów ${ }^{17}$.

Po drugie, istnieją olbrzymie różnice pomiędzy poziomem aktywności użytkowników na poszczególnych profilach. Zdecydowanie najpopularniejszy z punktu widzenia zarówno liczby polubień, jak i liczby znaczników „Osoby, które o tym mówią” okazał się Ruch Palikota. Partia ta zgromadziła ponad 44 razy więcej wyrazów sympatii („Lubię to!”) niż najmniej popularna w tej kategorii wśród ugrupowań parlamentarnych Solidarna Polska (odpowiednio:

16 Rok 2012 na polskim Facebooku podsumowuje Sotrender, http://marketing-news.pl/message. php?art=37367, odczyt z dn. 5.07.2013.

17 Było to dokładnie 177696214 polubień. Zob. Rok 2012 na polskim Facebooku podsumowuje Sotrender, http://marketing-news.pl/message.php?art=37367, odczyt z dn. 5.07.2013. 
Tabela 2. Statystyki aktywności użytkowników profili partii politycznych

\begin{tabular}{|c|c|c|c|}
\hline Nazwa partii & „Lubię to!” & „Osoby, które o tym mówią" & „Najczęstsza grupa wiekowa” \\
\hline PO & 26165 & 381 & $18-24$ lata \\
PiS & 10911 & 914 & $18-24$ lata \\
RP & 86684 & 2469 & $18-24$ lata \\
PSL & 10097 & 89 & $25-34$ lata \\
SLD & 4425 & 270 & $18-24$ lata \\
SP & 1938 & 476 & $18-24$ lata \\
KNP & 22381 & 2388 & $18-24$ lata \\
Zieloni 2004 & 2711 & 164 & $25-34$ lata \\
\hline Razem & 165312 & 7151 & \\
\hline
\end{tabular}

Źródło: opracowanie własne.

86684 i 1938 polubień). Ruch Palikota miał zresztą więcej polubień niż wszystkie pozostałe partie poddane analizie. Z kolei jeśli traktować funkcję „Osoby, które o tym mówią" jako - pośredni i uproszczony - miernik odzewu wywoływanego przez aktywność poszczególnych partii wśród użytkowników serwisów społecznościowych, to także w tym przypadku RP może pochwalić się największym sukcesem. Charakterystyczne jest, że drugie miejsce zajął w tej klasyfikacji z niewiele gorszym wynikiem - pozaparlamentarny KNP, a trzecie PiS, choć w tym ostatnim przypadku poziom odzewu był zdecydowanie mniejszy niż w przypadku RP (odpowiednio: 914 i 2469). Wyniki te pokazują, że polityczna aktywność internautów na Facebooku jest dobrym odzwierciedleniem obrazu dominującego w życiu publicznym, kreowanego przez tradycyjne media. Wszystkie partie liderujące w omawianej kategorii mają opinie ugrupowań wyrazistych programowo i budzących swymi działaniami duże emocje. Analiza Facebooka zdaje się to potwierdzać.

Warto jednocześnie podkreślić kwestię oczywistą, ale często bagatelizowaną przez entuzjastów wykorzystania ICT w polityce. Relatywnie duża aktywność użytkowników profili partii na serwisach społecznościowych i realna pozycja polityczna tychże ugrupowań to dwie całkowicie odrębne kwestie. Wyniki sondażu przedwyborczego prowadzonego przez CBOS w marcu 2012 roku, a więc w okresie którego dotyczą przytoczone rezultaty badań, wskazują, że największą popularnością cieszyła się PO - 31\%, przed PiS - 23\% i SLD - 12\%. Ruch Palikota odnotował w tym samym czasie $1 \%$ poparcia $^{18}$.

18 PO spada, PiS-owi rośnie, http://wyborcza.pl/1,76842,9441194,PO_spada_PiS_owi_rosnie. html, odczyt z dn. 6.07.2013. 
Po trzecie wreszcie, dostępna na profilach partii statystyka „Najczęstsza grupa wiekowa” wskazuje, że serwisy społecznościowe - także wtedy, gdy wykorzystywane są w kontekście życia politycznego - to domena osób najmłodszych. W przypadku sześciu spośród ośmiu analizowanych partii politycznych największy odsetek osób korzystających z partyjnych profili to ludzie w wieku 18-24 lata. Tylko w przypadku PSL i partii Zieloni 2004 internauci najaktywniejsi na profilach należą do nieco starszej grupy wiekowej (25-34 lata). Dane te nie zaskakują, ale warto mieć świadomość ich konsekwencji. W miarę dorastania coraz młodszych roczników konieczność docierania do wyborców poprzez sieć - w tym serwisy społecznościowe - będzie coraz bardziej bezalternatywna. O ile dzisiaj statystyczny polski wyborca to ciągle jeszcze reprezentant pokolenia wychowanego przed rewolucją informacyjną, o tyle w perspektywie kilkunastu lat większość społeczeństwa stanowić będą już ludzie nieznający świata bez Internetu. W świetle przytoczonych danych oznaczać to musi konieczność dokonania przez partie polityczne radykalnych zmian w modelu komunikowania $\mathrm{z}$ wyborcami.

Trzeci aspekt analizy obejmował dostępność na profilach partii politycznych różnego typu danych kontaktowych. Jeśli uznać, że interaktywność stanowi podstawową charakterystykę komunikowania sieciowego i jest kluczową przewagą Internetu nad tradycyjnymi mediami, to stopień wykorzystania istniejących w tym zakresie możliwości wiele mówi o strategii przyjmowanej przez konkretne partie polityczne.

Ten aspekt badań miał charakter binarny. W ramach kategorii „dostępność danych kontaktowych" wyodrębniono pięć szczegółowych kryteriów, a poszczególne profile analizowano z punktu widzenia realizacji każdego z nich (przyznając odpowiednio: „0” lub „1”). W ten sposób można wskazać zarówno typ kontaktu najczęściej udostępnianego przez partie na Facebooku, jak i te partie, których profile mają najbardziej interaktywny charakter. Wyniki prezentuje tabela 3.

Wydaje się zaskakujące, że jedynym kryterium spełnianym przez wszystkie analizowane profile było udostępnienie odnośnika do partyjnej witryny sieciowej. W przypadku większości instytucji - jak wspomniano już wcześniej - strony WWW wciąż spełniają rolę podstawowego narzędzia obecności w sieci i wydaje się, że nie inaczej jest w przypadku partii politycznych. Serwisy społecznościowe ciągle pełnią więc rolę dodatkowej, a nie „domyślnej” formy internetowej aktywności.

O ile adres siedziby partii znaleźć można na prawie wszystkich profilach (wyjątkiem jest RP), o tyle numer telefonu oraz e-mail dostępny jest tylko na pię- 
ciu spośród badanych profili. Najmniej rozpowszechniony typ danych kontaktowych to umieszczenie na profilu mapy lokalizującej siedzibę partii i ułatwiającej dotarcie potencjalnym zainteresowanym. Ten typ narzędzia dostępny jest tylko na dwóch profilach (SLD i Zieloni 2004).

Tabela 3. Dostępność danych kontaktowych na profilach partii politycznych

\begin{tabular}{|c|c|c|c|c|c|c|}
\hline \multirow{2}{*}{ Nazwa partii } & \multicolumn{5}{|c|}{ Typ danych } & \multirow{2}{*}{ Razem } \\
\cline { 2 - 6 } & Telefon & E-mail & Adres siedziby & Strona WWW & Mapa & \\
\hline PO & 1 & 1 & 1 & 1 & 0 & 4 \\
PiS & 1 & 1 & 1 & 1 & 0 & 4 \\
RP & 1 & 1 & 0 & 1 & 0 & 3 \\
PSL & 1 & 0 & 1 & 1 & 0 & 3 \\
SLD & 0 & 1 & 1 & 1 & 1 & 4 \\
SP & 0 & 0 & 1 & 1 & 0 & 2 \\
KNP & 0 & 0 & 1 & 1 & 0 & 2 \\
Zieloni 2004 & 1 & 1 & 1 & 1 & 1 & 5 \\
\hline Razem & 5 & 5 & 7 & 8 & 2 & 27 \\
\hline
\end{tabular}

Źródło: opracowanie własne.

Opisany obraz dostępności danych kontaktowych jest dosyć typowy i powiela błędny schemat myślenia rozpowszechniony wśród osób odpowiedzialnych za sieciową aktywność różnych instytucji. $U$ jego podstaw leży założenie, że każdy, kto trafia na profil partii na Facebooku, jest zainteresowany wyłącznie internetowymi formami kontaktu. Stąd powszechna obecność odnośników do stron WWW, ale pomijanie numeru telefonu (czy nawet adresu e-mail, który zapewne można znaleźć na partyjnej witrynie), a zwłaszcza tak tradycyjnych danych jak plan miasta $\mathrm{z}$ zaznaczoną lokalizacją. Tymczasem podstawowa zasada konstruowania narzędzi sieciowych brzmi: „Uczyń swój profil na tyle zindywidualizowanym, na ile to możliwe”. Trzeba więc dostarczyć niezbędne informacje zarówno temu, kto wszystkie swoje kontakty realizuje na serwisach społecznościowych, jak i osobie, która zajrzała tam wyłącznie dlatego, że została poproszona o sprawdzenie numeru telefonu do siedziby partii przez niekorzystającą z sieci babcię. Ignorowanie tej zasady wyklucza sporą liczbę obywateli z możliwości efektywnego kontaktu z przedstawicielami partii politycznej.

Analizując te same kwestie z perspektywy konkretnych ugrupowań, okazuje się, że najbardziej otwarta na interaktywność jest partia Zieloni 2004, której profil jest jedynym spełniającym wszystkich pięć kryteriów. Trzy kolejne partie (PO, PiS, SLD) uzyskały w tej klasyfikacji po 4 punkty, a profile RP i PSL spełniają 
po trzy kryteria. Stawkę zamykają SP i KNP, udostępniające na swych profilach wyłącznie adres siedziby i odnośnik do strony WWW. Ciekawy jest w tym kontekście zwłaszcza przypadek Ruchu Palikota, który - jak wynika z omówionych wcześniej danych - zdecydowanie najskuteczniej wykorzystuje Facebooka do budowania społeczności swych zwolenników. Jak się okazuje, dzieje się to do pewnego stopnia kosztem pielęgnowania kontaktów o nieco bardziej tradycyjnym charakterze.

\section{PODSUMOWANIE}

Przeprowadzona analiza dostarczyła wielu interesujących danych ilustrujących sposób wykorzystywania serwisów społecznościowych przez polskie partie polityczne. Obraz ten nie ma charakteru całościowego i niewątpliwie wymaga dalszej eksploracji. Już w chwili obecnej można jednak, odnosząc się do przedstawionych wcześniej dwóch hipotez, sformułować podstawowe wnioski.

Hipoteza pierwsza, zgodnie z którą partie polityczne w niewielkim stopniu wykorzystują na swych profilach interaktywne i multimedialne możliwości stwarzane przez sieć, została w dużym stopniu potwierdzona. Jak wykazały badania, nawet na poziomie elementarnym, bo dotyczącym danych kontaktowych, zdecydowana większość analizowanych profili nie realizowała wszystkich stwarzanych przez Internet możliwości. W tej sytuacji jeżeli użytkownicy serwisów społecznościowych wchodzą w interaktywną relację z politykami, to dzieje się to raczej pomimo braku spójnej strategii partii politycznych w tym zakresie niż dzięki ich konkretnym działaniom.

W kontekście multimedialności sprawa jest nieco bardziej skomplikowana. Na profilach partii znajduje się olbrzymia liczba fotografii. W tym sensie analizowane serwisy mają charakter multimedialny. Zdjęcia mają jednak ze swej natury charakter przede wszystkim ilustracyjny, w niewielkim stopniu wzbogacają treść dostępnego w sieci przekazu. Z tego punktu widzenia znacznie bardziej efektywne byłoby wykorzystanie materiałów filmowych, co jednak ma miejsce w bardzo ograniczonym zakresie.

Druga hipoteza („Znaczenie odgrywane przez partię polityczną na scenie publicznej nie ma wpływu na intensywność wykorzystywania przez tę partię serwisów społecznościowych oraz na aktywność użytkowników na partyjnych profilach”) została w pełni potwierdzona. Najsilniejsze - i dysponujące największymi zasobami finansowymi - partie z punktu widzenia wielu analizowanych 
kategorii miały profile znacznie uboższe niż ugrupowania cieszące się słabszym poparciem. Podobna prawidłowość dotyczy także stopnia aktywności użytkowników na poszczególnych profilach. Bezkonkurencyjny z tego punktu widzenia Ruch Palikota nigdy nie był dominującą siłą polityczną, a w ciągu ostatnich lat jego pozycja uległa wyraźnemu osłabieniu. Oznacza to, że z jednej strony skuteczne komunikowanie $\mathrm{z}$ wyborcami w sieci nie gwarantuje ciągle sukcesu politycznego w skali kraju, z drugiej zaś słabe wykorzystywanie Internetu nie musi przekładać się na wyborczą porażkę. ICT odgrywają w polityce coraz istotniejszą rolę, ciągle jednak jesteśmy daleko od momentu, w którym wykorzystanie technologii decydowałoby o losach politycznych ugrupowań. 